Article

\title{
Exploring the Relationship between Business Elite Networks and Redistributive Social Policies in Latin American Countries
}

\author{
Julián Cárdenas
}

Alice Salomon University of Applied Sciences Berlin, 12627 Berlin, Germany; julian.cardenas@onlinebschool.com

Received: 24 November 2019; Accepted: 16 December 2019; Published: 18 December 2019

check for updates

\begin{abstract}
Although the cohesion of business elites has been associated with income concentration and regressive policies, few studies have investigated in depth the role of business elite networks in macrosocial issues such as redistributive social policies. This research explores the relationship between business elite networks and redistributive social policies in several Latin American countries. To do so, this paper (1) examines business elite networks applying a network analysis of interlocking directorates, and (2) performs a cross-national comparative analysis of the cohesiveness of business elite networks, coverage and incidence of social protection and labor programs, and other variables. Results show that where business elites formed cohesive networks, social protection and labor programs were more inclusive. In conjunction with other factors, business cohesion plays a crucial role in business elites' acceptance of redistributive social policies because it enables long-term cost-sharing agreements, reduces uncertainty and internal divergent interests, and facilitates inducement.
\end{abstract}

Keywords: elite networks; business elites; redistributive social policies; social protection; interlocking directorates; Latin America

\section{Introduction}

When might business elites accept some redistributive social policies such as inclusive social protection and labor programs? Studies offer discordant conclusions regarding the link between business elites and the politics of redistribution. While some denoted the elites' fear of revolts as a prerequisite for redistribution and more egalitarian societies [1], others showed the social awareness of elites concerning the poor as a necessary condition [2,3]. Scholars also disagree on the role of business elite cohesion. Whereas some reported business cohesion as a source of power to block redistributive policies [4], others argued that cohesion of business elites gives rise to distributive institutions and engagement with the larger national issues $[5,6]$. To contribute to these debates, I introduce a new variable on the discussion that directly involves top businesspeople and measures business cohesion: business elite networks.

The present study focuses on the networks established by business elites among themselves, as they can be the means to facilitate (or hamper) collective agreements, peer inducement, and long-term cost-sharing projects. Analyses of business elite networks conducted by studying interlocking directorates have shown the influence of these corporate ties in the adoption of business practices [7], strategies to anti-corporate protests [8], and support (or refusal) to economic, commercial and environmental policies [9-11]. Therefore, business elite networks can foster one particular type of policy or another. Regarding social policy, business has usually less clearly defined preferences, and business elites respond to rather than lead social reforms [12]. Business elite networks, as a form of social organization, might affect these preferences and responses. Although the formation of networks among business elites is traditionally associated with income concentration, state capture and regressive 
tax policies $[4,13,14]$, the relationship between business elite networks and redistributive social policies has not properly been investigated.

The objective of this research is to explore the relationship between business elite networks measured through networks of interlocking directorates, and redistributive social policies measured through the inclusiveness of social protection and labor programs. To achieve this goal, a cross-national comparative analysis was carried out on networks of interlocking directorates among the 50 largest corporations in each country, coverage and incidence of social protection and labor programs, and other variables in five Latin American economies. After considering alternative explanations, I identify that where business elites formed a cohesive network, social protection and labor programs were more inclusive. Three underlying mechanisms through which business cohesion affects the business elites' acceptance of redistributive social policies were laid out.

Latin American countries provide an excellent opportunity to explore the relationship between business elite networks and redistributive social policies for three main reasons. First, despite the fact that Latin American countries have similar economic systems (or variety of capitalism) based on business groups and an atomistic labor market [15], and have enjoyed a sustained GDP per capita growth and a reduction of income inequality since the early 2000s, marked differences in welfare redistribution and social protection remains between these economies, e.g., inclusive in Chile and non-inclusive in Colombia. These lasting differences might be associated with divergences in other deep-rooted structures, and not only cyclical factors. Second, in emerging economies such as those of Latin America, where some institutions are weak (such as those related to the tax system and law enforcement), business networking plays an important role in regulating how resources are allocated. Finally, few studies have analyzed business elite networks in Latin America and have focused more on describing the network structures than on assessing the relationship with macro-level outcomes [16-19]. The present research contributes to the ongoing debates on the business elites and redistributive social policies, and the possible effects of business elite networks in macro-social issues on the basis of the analysis of Latin American countries.

This paper is organized as follows. Section 2 develops the analytical framework, focusing on the political effects of business elite networks, the role played by business cohesion in shaping redistributive policies, and alternative explanations for redistribution. Methods and data are outlined in Section 3. In Section 4, results are presented. Section 5 discuss the findings, focusing on the mechanisms between business cohesion and redistributive social policies. The last section concludes with the contributions along with avenues for future research.

\section{Business Elites and Redistributive Social Policies}

\subsection{Business Elite Networks}

Business elite networks (or corporate networks) are the set of connections created by the interplay among the people who lead and govern large corporations. The positions that provide direct opportunities to lead and govern companies are boards of directors. When directors sit simultaneously on several boards, this creates interlocks between the corporations to which they belong. The set of ties between large corporations and shared directors forms networks of interlocking directorates, also known as corporate networks or business elite networks. Networks of interlocking directorates are a proxy for the study of the social organization of business elites, as they show the structure of opportunities and constraints of business elites for collective action and coordination. Other networking mechanisms of business elites are business associations and informal meetings, but the former does not necessarily involve the CEOs and corporate directors, and the latter can embody more individual agency than organizational interests. Interlocking directorates capture the two faces of the networking among business elites: large corporations and top businesspeople. Research on networks of interlocking directorates has attracted the attention of many scholars, see Sapinski and Carroll (2017) [20] for a review. Although a growing number of them explored the consequences of 
interlocking directorates in politics $[9,21]$, they mostly focused on an organizational-level of analysis and barely explore the association of corporate networks with macro-level outcomes, to a certain extent due to the scarce cross-national comparative studies.

The interest in studying the relationship between elites and macro-social issues has increased after the financial crisis of 2008. Research has been focused on identifying when elites promote development or support redistributive welfare policies. Acemoglu and Robinson argued that institutions, often captured by elites, determine the growth and enrichment of some and not others, and the threat of revolution forces elites to democratize and accept some redistributive institutions [1,22]. DiCaprio noted that elites promote development when they see that there are incentives to do so, i.e., their particular interests align with general interests and social well-being [23]. A series of studies aimed at exploring when elites react to inequality and poverty have focused on analyzing the perception that elites have of the poor $[3,24]$. This literature is based on the idea of social awareness advocated by De Swaan et al. [2] who argued that if elites recognize poverty as a problem due to interdependence (it affects both rich and poor), responsibility (they must do something), or feasibility (it can be mitigated), then elites react and take action. But, the question that all these studies failed to answer is how business elites achieve agreements, common awareness about the poor, or shared perceptions about their threats and incentives. Here it is where business elite networks matter.

As some network theory suggests, network connectivity and stability create standard practices and rules of the game [25], while at the same time form a structure of incentives and constraints to share and articulate interests [26]. The networks that join business elites together create a framework for negotiation and diffusion of ideas that can affect the type of policies or laws that are ultimately passed. For example, Schneider showed that where business associations were all-encompassing, and thus more connected, big business collaborated closely with the government in the design and implementation of major economic reforms, such as free-trade agreements [27]. Also, Schoenman revealed that where business and political elites built broad networks, institutions emerged that benefited both and ensured the development of the economies, such as in Poland. In contrast, in countries such as Hungary and Romania, where elites were not widely interconnected, the development of market institutions was biased and benefited a small group over the collective good, resulting in lower rates of economic development [5].

\subsection{Business Cohesion and Redistributive Social Policies}

Cohesion is the property of a corporate network that is most helpful in understanding the possibility of aligning incentives and affecting policy-making because it determines the opportunities to undertake collective actions. Cohesion is a structural property of a network that refers to the extent that the social relations of members of a collective hold it together [28]. The cohesion of the network indicates the degree of connectivity, integration, and compactness. What sparks debate is whether business cohesion facilitates or, on the contrary, hampers the emergence of redistributive social policies. Some authors claimed that cohesion strengthens business elites' bargaining power and unifies opposition to policies that appear not to be in the interests of large corporations, while governments can have more bargaining leverage over a divided business [4]. Building on that, cohesive networks can be a mechanism of state capture to protect business interests against threatening political initiatives [14,29]. Other scholars showed that business cohesion, specifically extensive elite networks, facilitates the emergence of distributive policies to satisfy the demands of all groups involved [5], and enables a normative consensus to embark upon long-term projects for the national interest $[6,30]$. Therefore, the debate over whether business elites are organized cohesively or in a scattered manner is not only a discussion about the internal organization of big business but is also a way of interpreting the capabilities of business elites to affect policy-making.

From 2000 onwards in Latin American countries, in a context of sustained economic growth, electoral competition for low-income voters [31] and emphasis on poverty reduction by international institutions, governments aimed to boost some redistributive policies such as expansion of social 
protection and tax reforms. State administration had to negotiate with business elites to prevent these initiatives from being blocked, as several authors noted $[4,32,33]$. Business elites feared that rising social spending would lead to corporate and personal income tax increases. But, redistribution was also an opportunity for elites to increase the purchasing power of middle and lower classes, and integrate vulnerable groups into market structures, as the World Bank and IMF noted $[34,35]$.

The acceptance of long-term cost-sharing projects of redistribution requires underlying structures that facilitate agreements and inducement among business elites. Theories and studies on network analysis showed that cohesive networks promote the mobilization of resources for collective action [36], more participation of actors [37], effective transfer of information [38], reduction of uncertainty and transaction costs [39], similar behavior [40], shared beliefs [41], consensus [42], and may even increase the legitimacy of actions. Network cohesion also generates opportunities for social control and peer-inducement, which brings more standardization of preferences, and less autonomy [43,44]. Therefore, in cohesive networks, agreements and acceptance can emerge more easily.

However, the agreements among business elites can be for the majority of the population beneficial, such as acceptance of redistributive social policies, or harmful, such as pushing for fiscal policies oriented to benefit particular interests in detriment to the rest. That is why the presence of a cohesive business elite network by itself is unable to explain redistributive policies, and it requires a combination of other conditions.

\subsection{Alternative Explanations for Redistributive Social Policies}

Alternative explanations for the extension of redistributive policies can be grouped into six dimensions: colonial heritage [22,45,46], democracy [32,47,48], economic growth [49], agrarian structure [50], partisanship [51], concentration of production [52], and international trade. According to previous studies, redistributive social policies are more inclusive in non-colonial countries, advanced democracies, less agrarian economies, leftist or center-left governments, and countries with a low concentration of production. Trade has a more controversial role.

The literature on the link between international trade and redistributive social policies offers conflicting expectations. Some studies argue that trade liberalization forces the state to reduce social expenditure in order to maintain international competitiveness. Others indicate that trade openness increases emphasis on human capital and more efficient expenditure, such as targeted social assistance [53]. In Latin America, economic internationalization increased inequality during the 1990s due to an augment in skills premiums and a more neoliberal political orientation [54,55]. But, from the early 2000s, prices of commodities (fuels, minerals and agriculture) steadily increased due to growing demand from large emerging market economies like China and India, and income available to the governments from royalties, corporate income taxes, and profits of state-owned activities in these sectors ensured an increasing share of the trade income was available for redistribution. However, the high dependence of trading and non-trading large corporations on international markets might affect the position of business elites regarding domestic issues. Although internationalized business elites are more challenging to be taxed and can be less concerned about domestic issues, some authors claim that they are more willing to make concessions that reduce domestic social conflict and incentivize production $[22,47,50]$.

\section{Methods and Data}

I employed a cross-country and comparative approach to test alternative explanations and identify which business elite network, cohesive or fragmented, is associated with inclusive redistributive social policies. Although countries are becoming increasingly internationalized, social policies are still implemented at the national level. Besides, countries continue to be the main space for the interaction and creation of business elite networks in Latin America [56]. Five countries were selected: Mexico, Chile, Peru, Brazil, and Colombia. Although the original intention was to include the eight largest economies in the region in the study, data on directors of large corporations were not available for 
Argentina, Venezuela, and Ecuador. A caveat is that two of the most egalitarian countries in the region, Argentina and Uruguay, were not included. Despite this limitation, countries selected are comparable because they have similar economic and political backgrounds (Iberian colonial heritage, democratic regimes, similar cultural values, and the same variety of capitalism) but significant lasting differences in redistributive social policies.

Redistributive social policies, those that move resources from one group to another [57], were measured through social protection expansion and performance indicators. Social protection was chosen as it has a high redistributive effect and generates social inclusion $[49,58,59]$. Although the reduction of the GINI between 2006 and 2015 in Latin America was mostly due to the reduction in inequality in labor wages, the incidence of social protection policies on the poor and lower classes significantly correlates with GINI reduction estimates (Figure 1). Higher levels of coverage and incidence of social protection and labor programs indicate more inclusive redistributive social policies.

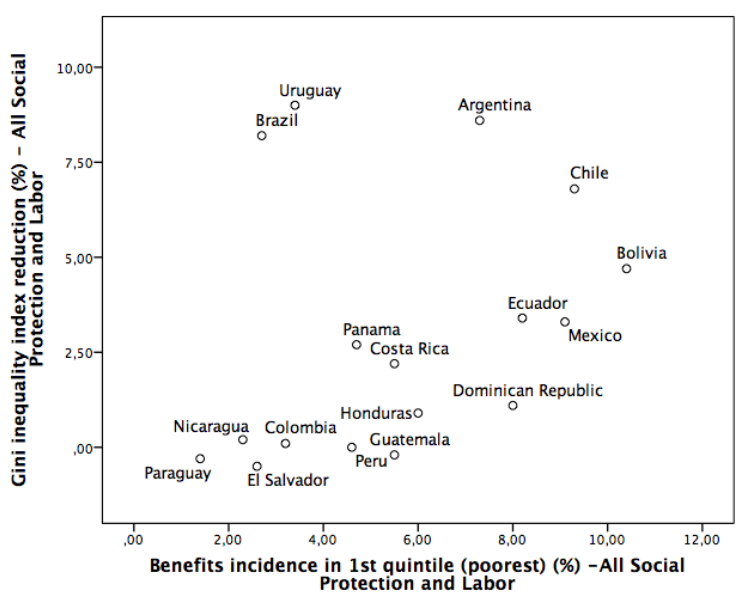

(a)

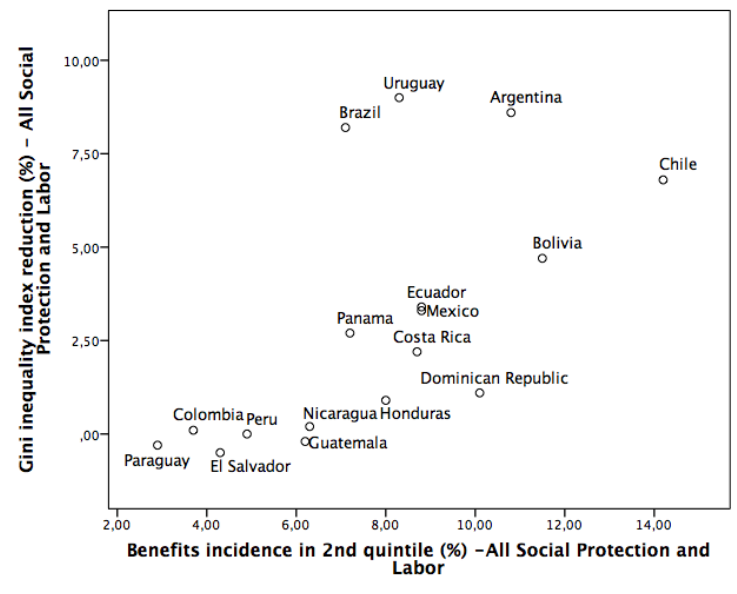

(b)

Figure 1. Benefits incidence of all social protection and labor programs in (a) $1^{\text {st }}$ quintile and (b) $2^{\text {nd }}$ quintile, and GINI inequality reduction due to these programs (average values 2006-2015). Source: own elaboration based on Aspire Atlas (World Bank 2016). Benefits incidence is the percentage of all transfer benefits going to the quintile. GINI inequality index reduction is due to all social protection and labor programs as percentage of pre-transfer GINI index.

The total social protection was calculated from social assistance, social security and labor market transfer programs. Specifically, measurements were taken of the level of coverage of these programs for the whole population, the level of coverage for the first (poorest) quintile ( $20 \%$ of the population with the lowest income), the level of coverage for the second quintile, and the incidence that these transfer programs have in the first (poorest) and second quintile [60]. As the comparison of structures was of more interest than the annual variations, and because of the sparseness of data, average values were calculated for the period 2006-2015.

For the analysis of business elite networks, interlocking directorates among the 50 largest corporations in each country were identified. The list of the top 50 firms, which included three-quarters of non-financial corporations ranked by assets and a quarter of financial corporations ranked by revenues, was obtained from América Economía magazine and national stock indexes. Data on board members were collected from companies' annual reports of 2014. Network analysis was applied to examine each inter-firm network using cohesion measures: connectedness, density, average degree, component ratio, main component size, isolates, and compactness.

Several alternative explanatory variables for redistributive social policies were considered from previous studies on determinants of redistribution and social protection: economic performance through GDP per capita and GDP per capita growth, size of the economy through GDP, agrarian 
structure through percentage of rural population and value-added agriculture, partisanship through years of leftist or center-left governments, and product concentration of exports through the Herfindahl Hirschman index. Colonial heritage and democracy variables were not included because the five countries present constant values: all countries are former Iberian colonies and not full democracies according to Polity IV, except for Chile. To measure the degree of trade internationalization and commodity wealth, the value of the exports of goods and services as a percentage of the gross domestic product ( $\%$ of GDP), and commodity exports (\% of total exports) were selected respectively [61]. Moreover, the number of top Latin American transnational corporations (multilatinas) was computed to check the internationalization of business elites [62].

\section{Results}

\subsection{Redistributive Social Policies}

Countries with the most inclusive social protection and labor programs out of the five analyzed were Chile, Mexico, and Peru. Those with less coverage and incidence of social protection were Colombia and Brazil. Table 1 compares the level of coverage (percentage of households where at least one member participates in social protection and labor program transfers) and benefits incidence in the poorest (percentage of benefits going to the poorest quintiles) by country. The average percentage of social protection coverage between 2006 and 2015 was $88 \%$ in Chile, $76.1 \%$ in Mexico, and 66.9\% in Peru, while Colombia reached $54.6 \%$ and Brazil $49.0 \%$. The most extensive coverage in social and labor protection for the poorest and second quintile occurred in Chile, Mexico and Peru, with over $75 \%$ being covered. Countries in which the poorest received the most benefits were Chile and Mexico, where approximately $9 \%$ of total benefits covered the poorest. In sum, the high-income inequality in all Latin American countries was differently mitigated. In Chile, Mexico and a certain degree in Peru, redistributive social policies were more inclusive than in Colombia and Brazil. Because these cross-national similarities and differences persist over time (Figure 2), other longue durée structures can be related to them, and not only the economic cycle or the ideological orientation of the government in power.

Table 1. Coverage and incidence of all social protection and labor programs \pm .

\begin{tabular}{|c|c|c|c|c|c|}
\hline & Mexico & Chile & Peru & Colombia & Brazil \\
\hline $\begin{array}{l}\text { Average \% coverage of all social protection } \\
\text { and labor programs - total population } \\
(2006-2015)(\mathrm{SD})^{*}\end{array}$ & $\begin{array}{l}76.1 \\
(5.4)\end{array}$ & $\begin{array}{l}88.0 \\
(3.2)\end{array}$ & $\begin{array}{l}66.9 \\
(11)\end{array}$ & $\begin{array}{l}54.6 \\
(7.5)\end{array}$ & $\begin{array}{l}49.0 \\
(4.5)\end{array}$ \\
\hline $\begin{array}{l}\text { Average \% coverage of all social protection } \\
\text { and labor programs }-1^{\text {st }} \text { (poorest) quintile } \\
(2006-2015)(S D)^{* *}\end{array}$ & $\begin{array}{l}76.1 \\
(7.8)\end{array}$ & $\begin{array}{l}96.3 \\
(0.3)\end{array}$ & $\begin{array}{l}85.7 \\
(3.7)\end{array}$ & $\begin{array}{l}68.3 \\
(9.2)\end{array}$ & $\begin{array}{l}48.5 \\
(17)\end{array}$ \\
\hline $\begin{array}{l}\text { Average \% coverage of all social protection } \\
\text { and labor programs }-2^{\text {nd }} \text { quintile } \\
(2006-2015)(S D)^{* *}\end{array}$ & $\begin{array}{l}74.4 \\
(8.5)\end{array}$ & $\begin{array}{l}94.7 \\
(1.2)\end{array}$ & $\begin{array}{l}77.3 \\
(8.0)\end{array}$ & $\begin{array}{l}63.0 \\
(11)\end{array}$ & $\begin{array}{l}48.9 \\
(7.4)\end{array}$ \\
\hline $\begin{array}{l}\text { Average } \% \text { benefits incidence in the } 1^{\text {st }} \\
\text { (poorest) quintile (2006-2015) (SD) *** }\end{array}$ & $\begin{array}{c}9.1 \\
(2.3)\end{array}$ & $\begin{array}{l}9.3 \\
(0.9)\end{array}$ & $\begin{array}{c}4.6 \\
(0.5)\end{array}$ & $\begin{array}{c}3.2 \\
(0.4)\end{array}$ & $\begin{array}{c}2.7 \\
(1.0)\end{array}$ \\
\hline $\begin{array}{l}\text { Average \% benefits incidence in the } 2^{\text {nd }} \\
\text { quintile (2006-2015) (SD) *** }\end{array}$ & $\begin{array}{l}8.8 \\
(2.3)\end{array}$ & $\begin{array}{l}14.2 \\
(1.3)\end{array}$ & $\begin{array}{l}4.9 \\
(0.6)\end{array}$ & $\begin{array}{c}3.7 \\
(0.1)\end{array}$ & $\begin{array}{c}7.1 \\
(1.3)\end{array}$ \\
\hline
\end{tabular}

Source: own elaboration from World Bank (2016). \pm Data from World Bank - Aspire: The Atlas of Social Protection Indicators of Resilience and Equity. No data exist before 2006. Average values and standard deviations (SD). * Estimated percentage of population participating in social protection and labor transfer programs (includes direct and indirect beneficiaries); ** Percentage of individuals in the quintile who live in a household where at least one member receives the transfer; ${ }^{* * *}$ Percentage of transfer benefits going to the quintile, benefit incidence is equal to (sum of all transfers received by all individuals in the quintile)/(sum of all transfers received by all individuals in the population). The indicator includes both direct and indirect beneficiaries. 


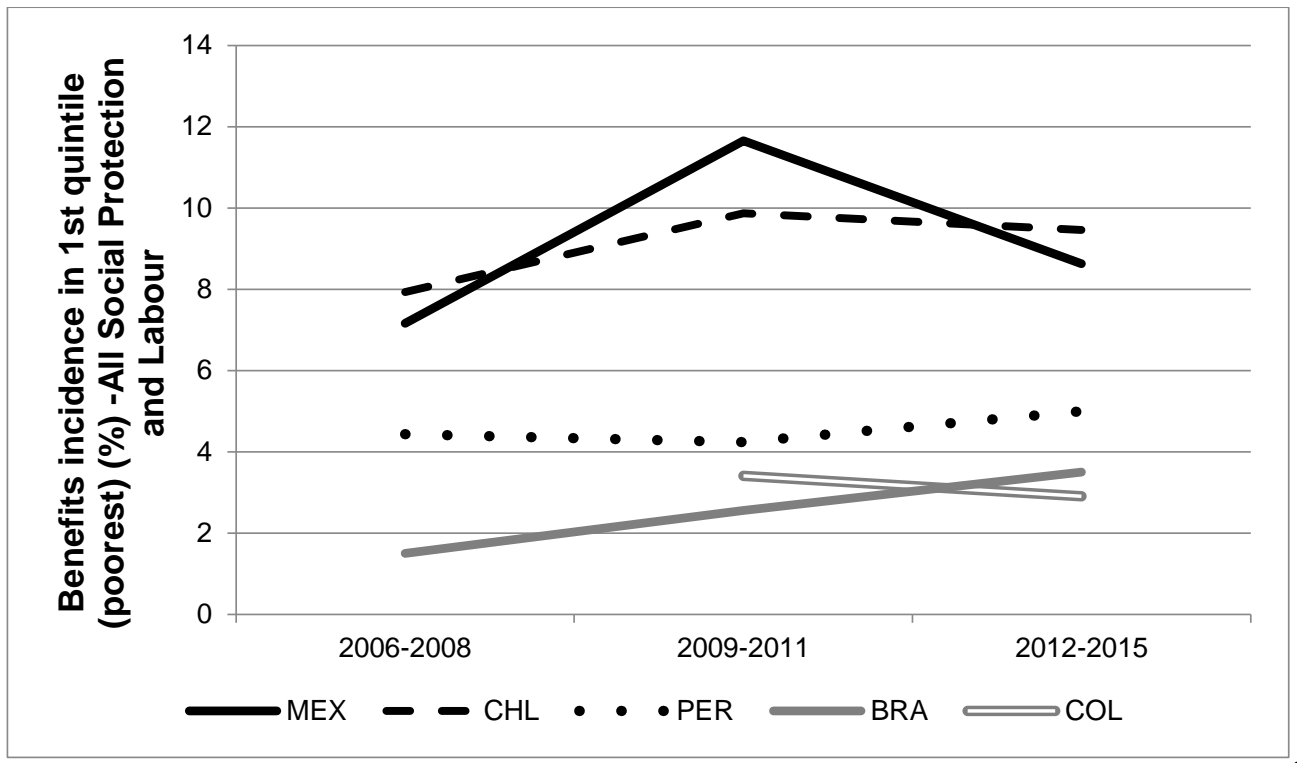

Figure 2. Benefits incidence (percentage of transfer about social protection and labor programs) going to the $1^{\text {st }}$ quintile (poorest), average values for each period, World Bank (2016).

\subsection{Testing Alternative Explanations}

Literature has paid attention to several variables to explain the similarities and differences in the trajectory and dynamic of redistributive social policies. Table 2 displays the values of possible explanatory variables for redistribution and show that the countries analyzed are large and medium-sized economies in the region, experienced significant economic growth since 2000, and the rural population size and GDP-share of agriculture were below the regional mean. These features can explain the increase in social expenditure, but not the differences across Latin American countries. The enlarged size of the economy does not guarantee the rise of inclusive social policies, as also some literature has suggested [49].

Table 2. Alternative explanatory variables for redistributive social policies: average values for the period 2005-2014.

\begin{tabular}{|c|c|c|c|c|c|c|c|}
\hline & \multirow{2}{*}{$\begin{array}{c}\text { Size of the } \\
\text { Economy } \\
\text { GDP } \\
\text { (constant } \\
2010 \text { US\$ } \\
\text { billion) } \\
\text { (2005-2014) }\end{array}$} & \multicolumn{2}{|c|}{ Economic Performance } & \multicolumn{2}{|c|}{ Agrarian Structure } & \multirow{2}{*}{$\begin{array}{c}\begin{array}{c}\text { Product } \\
\text { Concentration } \\
\text { of Export }\end{array} \\
\text { Product } \\
\text { concentration } \\
\text { index }(\mathrm{HH}) \\
(2005-2014) *\end{array}$} & \multirow{2}{*}{$\begin{array}{c}\text { Partisan-ship } \\
\text { Years of a } \\
\text { leftist or } \\
\text { center-left } \\
\text { govern-ment } \\
(2000-2014)\end{array}$} \\
\hline & & $\begin{array}{c}\text { GDP per } \\
\text { capita } \\
\text { (constant } \\
2010 \text { US\$) }\end{array}$ & $\begin{array}{c}\text { GDP per } \\
\text { capita } \\
\text { growth \% } \\
(2000-2014)\end{array}$ & $\begin{array}{c}\text { Rural } \\
\text { population } \\
\% \text { of total } \\
\text { population } \\
(2005-2014)\end{array}$ & $\begin{array}{l}\text { Agriculture, } \\
\text { value } \\
\text { added, \% } \\
\text { of GDP } \\
(2005-2014)\end{array}$ & & \\
\hline Mexico & 1.07 & $9,152.1$ & 9.6 & 22.3 & 3.41 & 0.15 & 0 \\
\hline Chile & 0.22 & $12,996.7$ & 55.3 & 11.6 & 4.04 & 0.36 & 11 \\
\hline Peru & 0.14 & $4,906.7$ & 75.9 & 23.3 & 7.53 & 0.26 & 9 \\
\hline Colombia & 0.29 & $6,292.1$ & 53.1 & 25.1 & 7.19 & 0.32 & 0 \\
\hline Brazil & 2.14 & $10,893.4$ & 68.8 & 15.8 & 5.16 & 0.13 & 11 \\
\hline $\begin{array}{c}\text { Latin } \\
\text { America } * *\end{array}$ & 0.29 & & & 27.3 & 8.63 & & \\
\hline
\end{tabular}

Source: own elaboration based on World Bank (2019) and UNCTAD (2018) * Product concentration of exports is the normalized Herfindahl Hirschman index. Values range from 0 to 1 . Countries with a preponderance of trade in just a few products would have an index close to 1, though a low value of the index may result if the export values of these products are similar [63]. ** Average value of the Latin American countries, excluding Puerto Rico and Cuba.

Regarding product concentration of exports, Brazil and Mexico were the most diversified countries in the region; Chile and Colombia, on the contrary, had a very concentrated economy. However, 
these cross-national similarities and differences did not correspond to those in social policy. The political orientation of the party in government was also unable to explain the diversity of welfare policies. Inclusiveness of social protection was high in Mexico under the right governments, and low in Brazil under the left governments. Previous studies also found that redistributive policies were implemented during right-wing governments in Latin America [31]. Certainly, all these factors contribute to understanding the politics of redistribution, but they alone are not sufficient to explain the lasting similarities and differences of social protection between Latin America countries.

\subsection{International Trade}

Table 3 compares the countries based on three measures of international trade: the degree of commodity-dependence, export value (\% GDP), and the number of multilatinas. Although commodity exports significantly increased in all the economies and can explain the higher availability of trade income in hands of governments, differences in commodity wealth do not correspond to those on social protection. In economies where social protection was inclusive, like Mexico, commodity represented only $24 \%$ of total exports in 2013. In commodity-rich economies like Colombia, social protection was non-inclusive.

Table 3. International trade.

\begin{tabular}{|c|c|c|c|c|c|}
\hline & Mexico & Chile & Peru & Colombia & Brazil \\
\hline $\begin{array}{l}\text { Commodity (fuels, minerals, agriculture) exports } \\
\text { (\% total exports) } 2003 *\end{array}$ & 18.5 & 81.7 & 83.4 & 66.3 & 47.4 \\
\hline $\begin{array}{c}\text { Commodity (fuels, minerals, agriculture) exports } \\
\text { (\% total exports) } 2013 *\end{array}$ & 24.0 & 87.0 & 88.2 & 83.3 & 62.9 \\
\hline Average export value (\% GDP) 2005-2014 (SD) ** & $\begin{array}{l}29.5 \\
(2.4)\end{array}$ & $\begin{array}{l}38.0 \\
(3.8)\end{array}$ & $\begin{array}{c}27 \\
(2.6)\end{array}$ & $\begin{array}{l}17.1 \\
(1.0)\end{array}$ & $\begin{array}{l}12.4 \\
(1.6)\end{array}$ \\
\hline Number of multilatinas in the top $30^{* * *}$ & 9 & 8 & 0 & 2 & 5 \\
\hline
\end{tabular}

Source: own elaboration from * UNCTAD (2018), ** World Bank (2019), and *** América Economía (2018).

Regarding export-led growth, the countries that were more oriented towards international trade, with exports that accounted for a significant share of the GDP, were those where social protection and labor programs were more inclusive: Chile, Mexico, and Peru (Table 3). The average exports of goods and services between 2005-2014 accounted for 37\% of the GDP in Chile, 30\% in Mexico and 27\% in Peru, whereas in Colombia, exports represented $17 \%$ and in Brazil, $12 \%$ of the GDP. If the trend during 1990-2014 is analyzed, it can be seen that except for Chile, the other economies started from similar levels but some, such as Mexico and Peru, opted for export-led growth, while Colombia's and Brazil's economy was more based on the internal market (Figure 3). In the ranking of multilatinas of 2014 that computes among other measures sales and employees abroad, of the 30 top transnational corporations, 9 were Mexican, 8 Chilean, 5 Brazilian and 2 Colombian. Mexican and Chilean business elites were more internationalized and dependent on international markets. In sum, in economies with high international trade, social protection and labor programs were more inclusive. 


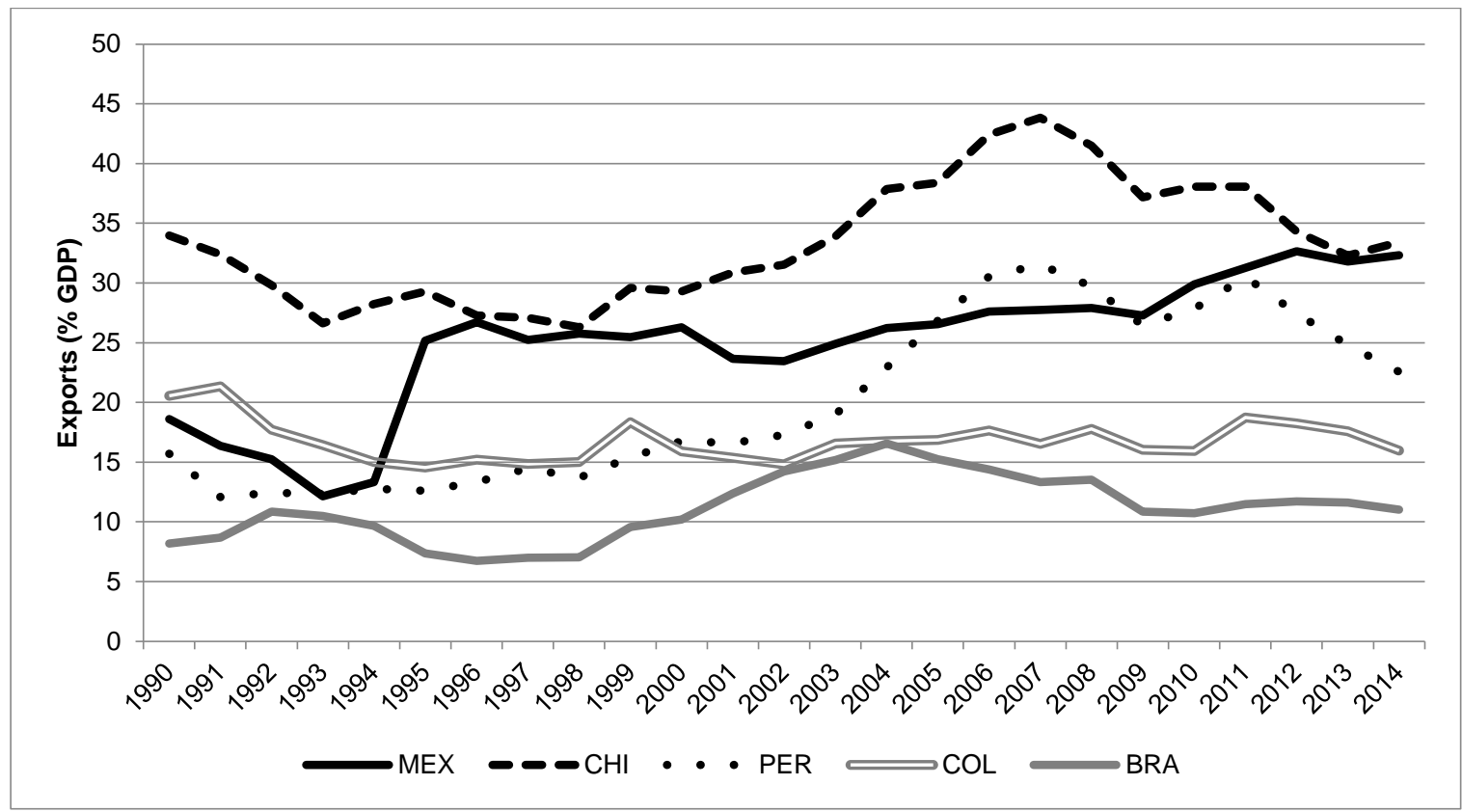

Figure 3. Exports (\% of GDP) 1990-2014, World Bank (2019).

\subsection{Comparison of Business Elite Networks}

The most cohesive business elite networks were those from Mexico and Chile, followed by Peru. The corporate networks in Colombia and Brazil were more scattered or fragmented. Table 4 shows the network cohesion measures for corporate networks. The business elite networks in Mexico and Chile presented a high connectedness, density and average degree, low component ratio, a large main component, few isolated nodes and high compactness, while the networks in Colombia and Brazil had low connectedness, density and average degree, high component ratio, their main component was medium-sized, and they had many isolated nodes and low compactness. Peru's corporate network was in an intermediate position. As network cohesion measures showed a high correlation with each other, an index of cohesion was calculated based on a principal component analysis. A single factor was extracted, and regression scores were calculated for each case. Table 4 displays the values of cohesion measures for each national corporate network. Mexico had the highest score in the index of cohesion (1.42), followed by Chile (0.47), and then Peru (-0.01), with Colombia and Brazil having much lower scores ( -0.91 and -0.96 respectively).

Table 4. Cohesion measures for corporate networks.

\begin{tabular}{cccccc}
\hline & Mexico & Chile & Peru & Colombia & Brazil \\
\hline Cohesion index & 1.42 & 0.47 & -0.01 & -0.91 & -0.96 \\
\hline Connectedness & 0.64 & 0.52 & 0.38 & 0.14 & 0.10 \\
Density & 0.14 & 0.05 & 0.04 & 0.02 & 0.02 \\
Average degree & 6.76 & 2.64 & 2.04 & 1.20 & 1.12 \\
Component ratio & 0.18 & 0.25 & 0.35 & 0.55 & 0.51 \\
Main component size (\%) & 80 & 72 & 62 & 38 & 24 \\
Isolates (\%) & 16 & 20 & 30 & 46 & 42 \\
Compactness & 0.36 & 0.20 & 0.16 & 0.06 & 0.06 \\
\hline
\end{tabular}

$\mathrm{N}=$ top 50 firms in each country; Cohesion index: regression scores via principal component analysis; Connectedness: 1 minus the proportion of pairs of nodes that are unreachable; Density: number of existing ties out of the total possible; Average degree: number of total ties divided by the total number of nodes; Component ratio: number of components minus 1 divided by number of nodes minus 1, the lower the component ratio, the less fragmented the network; Main component size (\%): percentage of nodes that belong to the main component (set of nodes and ties where all nodes are connected by a path); Isolates (\%): percentage of nodes without any tie; Compactness: harmonic mean of all distances between nodes. All indicators were calculated with the dichotomized matrix. 
A cross-national analysis of social protection, business elite networks, and explanatory variables for redistribution, summed up in Table 5, showed that a combination of sustained economic growth, high international trade, and a cohesive business elite network was present when inclusive social protection and labor programs arose, such as in Mexico and Chile, and to some extent in Peru. On the contrary, in countries with non-inclusive social protection (Colombia and Brazil), cohesive business elite networks were absent.

Table 5. Comparative analysis of cases with inclusive and non-inclusive social protection.

\begin{tabular}{|c|c|c|c|c|c|c|c|}
\hline & $\begin{array}{l}\text { Business } \\
\text { Elite } \\
\text { Networks }\end{array}$ & $\begin{array}{c}\text { Trade } \\
\text { Internationalization } \\
*\end{array}$ & $\begin{array}{c}\text { GDP } \\
\text { Growth } \\
(2000-2014)\end{array}$ & $\begin{array}{c}\text { Rural } \\
\text { Population } \\
\text { (\% of Total } \\
\text { Population) * }\end{array}$ & $\begin{array}{c}\text { Agriculture, } \\
\text { Value } \\
\text { Added } \\
\text { (\% of GDP) } \\
*\end{array}$ & $\begin{array}{c}\text { Product } \\
\text { Concentration } \\
\text { of Exports * }\end{array}$ & $\begin{array}{c}\text { Ideological } \\
\text { Orientation } \\
\quad \text { of } \\
\text { Government } \\
(2000-2014)\end{array}$ \\
\hline & \multicolumn{7}{|c|}{ Inclusive social protection and labor programs } \\
\hline Mexico & Cohesive & High & Sustained & Medium-low & Very low & Low & Right \\
\hline Chile & Cohesive & High & $\begin{array}{l}\text { Sustained- } \\
\text { high }\end{array}$ & Very low & Low & High & Center-left \\
\hline \multirow[t]{2}{*}{ Peru } & $\begin{array}{l}\text { Medium } \\
\text { cohesive }\end{array}$ & High & $\begin{array}{l}\text { Sustained- } \\
\text { high }\end{array}$ & Low & Medium-low & Medium & Center-left \\
\hline & \multicolumn{7}{|c|}{ Non-inclusive social protection and labor programs } \\
\hline Colombia & $\begin{array}{c}\text { Not } \\
\text { cohesive }\end{array}$ & Medium & $\begin{array}{l}\text { Sustained- } \\
\text { high }\end{array}$ & Low & Medium-low & High & Right \\
\hline Brazil & $\begin{array}{c}\text { Not } \\
\text { cohesive }\end{array}$ & Low & $\begin{array}{l}\text { Sustained- } \\
\text { high }\end{array}$ & Very low & Very low & Low & Left \\
\hline
\end{tabular}

\section{Discussion}

Although business cohesion was present when social protection and labor programs were more inclusive, the relationship between business elite networks and redistributive social policies is complex and involves a combination of factors and mechanisms. Sustained economic growth is a necessary but not sufficient condition to boost redistributive social policies because it was also present in countries with non-inclusive social policies.

An export-led growth (high international trade) was only present where social protection and labor programs were more inclusive. Increases in commodity exports enhanced the government's incomes and capacity for social spending. Moreover, Mexican, Chilean and Peruvian business elites became more dependent on international markets. Consequently, the domestic market was no longer the main space for the accumulation of income and wealth. Given this change in the source of income, business elites tend to support democratic institutions that guarantee the control of private investments and reduce the risk of social conflicts, as Acemoglu and Robinson, Boix, and Moore have argued [22,47,50]. Democracy generates the increased participation of civil and political organizations that demand more redistribution. For instance, reforms in pensions and an increase in social spending during the presidency of Michelle Bachelet in Chile were preceded by lasting student protests contesting inequality in the educational system (2011) and in the pension system (2016) [64]. Internationalized business elites can be more open to accepting social policies partly to avoid the emergence of radical, threatening initiatives. Trade internationalization can give rise to more inclusive social policies, but by itself it cannot explain how the business elites accept these redistributive social policies. Business elites with distinguishing interests and sources of incomes, some more focused on international markets and others on the domestic market, can reach agreements more easily and be induced to accept redistributive projects thanks to the networks among them.

When political elites aim to boost some redistributive policies, the state negotiates with business elites to prevent these initiatives from being blocked. Here, business elite networks become essential because they affect the degree of acceptance of policies by business elites. Three interrelated mechanisms explain how business cohesion facilitates the business elites' acceptance of redistributive social policies (Figure 4). 


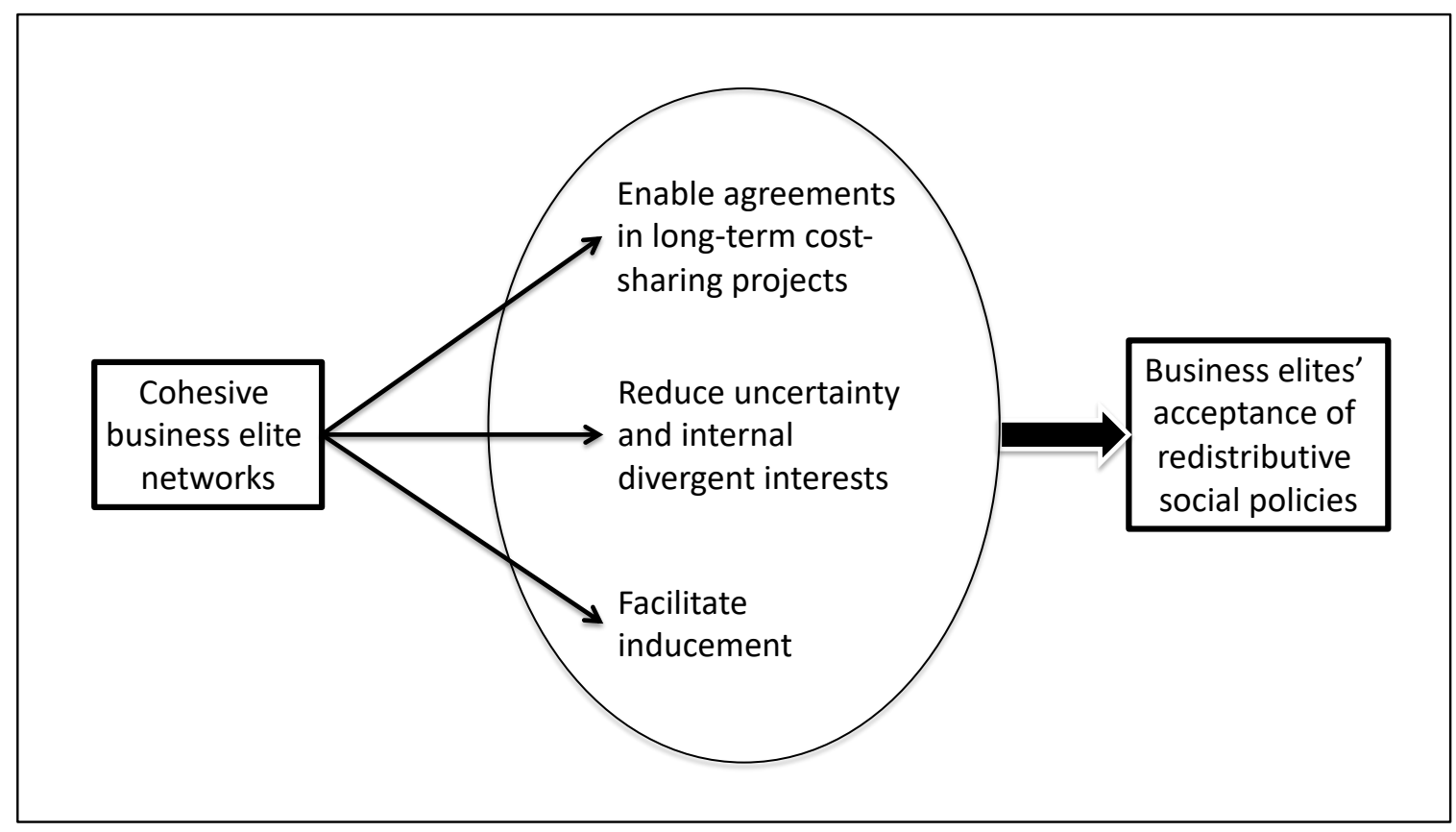

Figure 4. Mechanisms between business elite networks and redistributive social policies.

\subsection{Cohesive Business Elite Networks Enable Agreements in Long-Term Cost-Sharing Projects}

A large survey over business elites in several Latin American economies, including Mexico, Chile and Brazil, revealed that they are concerned about poverty and inequality and mostly agree that the solution comes from higher social spending and improvement of public services, but they are averse to paying more taxes [65]. The interest of business elites in reducing extreme poverty and inequality through social protection programs such as cash transfers and social assistance lies in incorporating vulnerable groups to the market, augmenting domestic consumption, and spurring the human capital of future generations $[59,66,67]$, which favors large business groups with investments in industry, banking, retail, telecommunications, construction and real estate sectors. The challenge is that business elites assume part of the cost of this redistribution because social spending affects debt ratio, and macroeconomic, fiscal and tax policies.

When the state undertakes actions of poverty alleviation and income redistribution, business elites do not block these initiatives if the costs are shared among all. Cohesive business networks enable cross-sectoral agreements and translate into leverage to negotiate with the state against progressive taxation, as some studies have claimed [4], but also to consent to an extension of social benefits. Business elite networks can serve to enhance the feasibility of doing something, one of the conditions pointed out by the theory of elites' social awareness about the poor [2]. When an individual action is taken, macrosocial problems are less likely to be mitigated, and the feeling of responsibility is reduced since inequality and poverty are considered to be a result of flaws in the system and not of a single agent.

Where business elites are fragmented, like in Brazil and Colombia, although an intention to sustain redistributive initiatives for increasing human capital or market integration might emerge, it clashes with the lack of structures to achieve normative consensus within the business sector and the difficulty in articulating long-term cost-sharing projects among business elites [6]. The governments of Brazil, under the Workers' Party (Partido dos Trabalhadores [PT]), and to a lesser extent the Colombian government, have made efforts to fight poverty through an increase in social spending, but they remain far from the levels of coverage and incidence of Chile or Mexico. The difficulties of the Brazilian and Colombian political elites for negotiating collectively with business elites and inducing acceptance has led to institutional instability in Brazil and intra-elite conflicts in Colombia during the peace process and its associated social reforms. For example, some large Colombian business groups supported the 
peace agreement while others financed the campaign against it. The social policies linked to the peace process in Colombia were a field of dispute between industrial and agriculture business elites, and between business groups from different regions. Colombian business elites were unable to agree on large social reforms due to the lack of platforms and connections for building consensus.

\subsection{Cohesive Business Elite Networks Reduce Uncertainty and Internal Divergent Interests}

The problem with supporting redistributive initiatives is that the benefits and risks are divergent for business elites. For instance, business elites may support or at least accept policies with progressive distributional effects at boom phases of the economic cycle and vetoing them in bust periods [68]. However, it is in bust periods when preferences most clearly diverge. Financial corporations seek to impose market discipline in order to ensure creditor claims, whereas business elites more embedded in the domestic market may be supportive of policies strengthening domestic demand. Business cohesion becomes an important system to articulate divergent interests and avoid internal conflicts by reducing uncertainty and augmenting social control [69].

For instance, the pension system in Chile is a fully funded capitalization system run by private sector pension funds (Pension Funds Administrators - Administradoras de Fondos de Pensión - AFPs). People can choose between five AFPs to manage their savings. Money collected by AFPs is invested in various economic sectors in the domestic market. Banks had always the goal of entering this profitable pension fund management business [70]. But, when President Michelle Bachellet aimed to reform the pension system first in 2008 to make it more inclusive (augmenting coverage and incidence) and in 2014 to create a state-owned pension fund, the Chilean banks remained passive and did not lobby to manage pensions. Although a proposal of allowing banks to enter the business was suggested by some members of the negotiating political committee, large Chilean banks aligned with pension trust funds to safeguard the private capitalization of the pension system. These large Chilean banks were highly interlocked with companies owned by private pension funds, which contributed to deal with the divergent interests. Moreover, when the preservation of the private pension system in Chile was more seriously challenged in 2016, the association of private pension funds appointed Andrés Santa Cruz as president. He was the former leader of the largest multi-sectoral business association, Confederation of Production and Commerce (CPC), and board member of the port commercial firm Puertos y Logística (2013-2018), a holding controlled by the Matte and Angellini families, two of the largest Chilean business groups. His recruitment represents an illustrative example of the relevance of board interlocks to reduce uncertainty and manage internal divergence in the business sector. Finally, private trust funds negotiated with the state and accepted a more inclusive system (extension of coverage for low-income individuals and increase of minimum pension) for satisfying the demands of redistribution. They preserved the control of pensions in part due to the banks' capacity to prioritize class-wide interests rather than sectorial.

\subsection{Cohesive Business Elite Networks Facilitate Inducement}

When business elites are organized into cohesive networks, and are therefore more concentrated, the state can negotiate with the business elites as a unitary bloc. In countries where business elites form a cohesive network, the agreements reached between the inner circle of the business sector and the state can be disseminated through the network, and more easily induced and accepted by the whole business sector due to the multiple positions of some directors [71]. For instance, a substantial segment of Mexican business elites from all economic sectors negotiated with the state, and finally accepted President Calderon's reform on taxing cash deposits and slightly increasing corporate tax incomes (2007) with the government's promises of infrastructure investments [31]. These agreements were easily assumed by big businesspeople, probably thanks to the multiple connections of some corporate directors across the business sector, e.g., a small inner group of 10 directors sat on one-third of the corporations listed in the Mexican Stock Exchange [72]. In countries with fragmented business elite networks, if the negotiations between the state and business elites are scattered, the agreements made 
by a few are less likely to be accepted by the rest. Besides, if business elites are more fragmented, the demands of each business group are more particularistic than class-wide.

\section{Conclusions}

A cohesive corporate network was present where redistributive social policies were more inclusive, along with sustained economic growth and high international trade. This finding suggests that although business cohesion can be a mechanism to protect business interest against the government, they can also facilitate long-term cost-sharing public-private projects of redistribution. Cohesive networks allow business elites to achieve agreements, reduce uncertainty, and manage divergent interests, but also cohesion can make big businesspeople more vulnerable in business-state negotiations. This fact explains why Latin American governments have avoided prohibiting interlocking directorates despite the several cases of collusion.

The relationship between business elite networks and redistributive social policies is not a linear correlational. It does not, therefore, mean that the higher the increase in the cohesion of the elites, the higher the proportional expansion of social protection. Rather, findings highlight the interdependence of elite networks and social policy, and how networking among business elites can have an unexpected "redistributive" effect on society. The decision to establish interlocking directorates is obviously not intended to build social policies in a given country, but corporate networks can have unintended consequences in politics and society.

As studies on the drivers of inequality in Latin America have pointed out, the decline of inequality since 2002 occurred due to improved macroeconomic conditions and better welfare distribution policies, but not by a high increase of taxes on large corporations or the super-rich [51,73]. Although tax revenue (\% of GDP) partially increased in some Latin American economies, progressive taxation is still very limited. Corporate income tax rates have been relatively constant from 2008 to 2014 [74]. Business groups have strongly opposed progressive taxation across Latin America [75]. The organization of business elites and its direct access to decision-making officials have eased the process of state capture, especially addressed to avoid tax increases. This raises the question of when business elite networks are a source of state capture and when they are not.

Other future studies should research in depth the relationship between business elite networks and inequality. Although longitudinal data on corporate networks were not available, some ideas about the relationship between business cohesion and redistributive policy outcomes can be drawn from the few previous studies. In Chile, the cohesion of the network increased between 1988 and 2005 [18]. It is ignored in what years exactly the large increase in interlocks took place, but when inequality began to fall in 2002 in Chile, the corporate network was more cohesive than in the 1980s and 1990s, the decades with the highest level of inequality. In Brazil, the analysis of interlocking directorates from 1997 to 2007 by Mendes-da-Silva showed that the period when the network cohesion was the highest was in 2003 and its surrounding years, again when income inequality decreased [17]. Even though these results are not deterministic, nor is it intended, they do show that in the moments when the income inequality fell steadily, the business elites were more cohesive. A limitation of the present study is the relatively small number of countries analyzed. Further studies should explore whether this pattern is reproduced when other economies are examined.

This paper provides some theoretical, empirical and methodological avenues for future research. At the theoretical level, future studies should widen theories of regulatory or state capture by incorporating insights from network analysis. Empirically, this study opens avenues to explore whether other types of elite networks, such as the interaction of business and political elites, affect issues such as inequality and poverty, especially when there is so much debate about the revolving doors between politics and business. Moreover, the different roles of directors within the board should be considered to find out whether business cohesion is sustained by shareholder directors or independent directors. At the methodological level, future steps should delve further into the development of causal models that link business elites, politics and inequality. Network analysis 
provides a map of actors and the ties among them. However, by itself, it is unable to explain any results that are not associated with these actors or ties, such as whether the cohesion of a corporate network leads to the emergence of a new policy. It becomes necessary, therefore, to combine methods that trace the whole process from the independent variable to the outcome of interest. Here, the application of the process tracing method would provide further insights into the identification of the different causal mechanisms, and the incidence of mediator variables. Moreover, structural equation modelling would allow for an analysis of indirect paths, and qualitative comparative analysis (QCA) would permit researchers to deal with the combination of causal conditions and the phenomenon of equifinality (the existence of multiple causal paths that lead to the same outcome). The challenge will be to mix all of these methods associated with causality to explore the macrosocietal effects of elite networks.

Funding: This research was funded by The Deutsche Forschungsgemeinschaft (DFG), grant number CA: 1272/1-1, and TrAndes - Postgraduate Program on Sustainable Development and Social Inequalities in the Andean Region.

Acknowledgments: The author thanks Francisco Robles-Rivera, Diego Martínez-Vallejo, Marianne Braig, Johanna Mair, Edgar Zavala-Pelayo, Constantin Groll, Markus Rauchecker, Bettina Schorr, César Guzmán-Concha, and Ignacio Schiappacasse for valuable comments and suggestions.

Conflicts of Interest: The authors declare no conflict of interest.

\section{References}

1. Acemoglu, D.; Robinson, J. Why Nations Fail: The Origins of Power, Prosperity, and Poverty; Crown Business: New York, NY, USA, 2012.

2. De Swaan, A.; Manor, J.; Øyen, E.; Reis, E.P. Elite Perceptions of the Poor: Reflections for a Comparative Research Project. Curr. Sociol. 2000, 48, 43-54. [CrossRef]

3. Reis, E.P.; Moore, M. Elite Perceptions of Poverty and Inequality; Zed Books: New York, NY, USA, 2005; ISBN 978-1-84277-639-1.

4. Fairfield, T. Private Wealth and Public Revenue in Latin America: Business Power and Tax Politics; Cambridge University Press: New York, NY, USA, 2015; ISBN 978-1-107-08837-5.

5. Schoenman, R. Networks and Institutions in Europe's Emerging Markets; Cambridge Studies in Comparative Politics; Cambridge University Press: Cambridge, UK, 2014; ISBN 978-1-139-38162-8.

6. Mizruchi, M.S. The Fracturing of the American Corporate Elite; Harvard University Press: Cambridge, MA, USA, 2013; ISBN 978-0-674-07536-8.

7. Haunschild, P.R. Interorganizational Imitation: The Impact of Interlocks on Corporate Acquisition Activity. Adm. Sci. Q. 1993, 38, 564-592. [CrossRef]

8. Banerjee, T.; Burroway, R. Business Unity and Anticorporate Protests: The U.S. Fortune 500 in 2010. Mobilization Int. Q. 2015, 20, 179-206.

9. Dreiling, M.; Darves, D. Corporate Unity in American Trade Policy: A Network Analysis of Corporate-Dyad Political Action. Am. J. Sociol. 2011, 116, 1514-1563. [CrossRef]

10. Jäger, K. Sources of Franco-German corporate support for the euro: The effects of business network centrality and political connections. Eur. Union Polit. 2013, 14, 115-139. [CrossRef]

11. Hein, J.E.; Jenkins, J.C. Why does the United States lack a global warming policy? The corporate inner circle versus public interest sector elites. Environ. Polit. 2017, 26, 97-117. [CrossRef]

12. Farnsworth, K.; Holden, C. The Business-Social Policy Nexus: Corporate Power and Corporate Inputs into Social Policy. J. Soc. Policy 2006, 35, 473-494. [CrossRef]

13. Domhoff, G.W. Who Rules America? The Triumph of the Corporate Rich, 7th ed.; McGraw-Hill Education: New York, NY, USA, 2013; ISBN 978-0-07-802671-3.

14. Crabtree, J.; Durand, F. Peru: Elite Power and Political Capture; Zed Books: London, UK, 2017; ISBN 978-1-78360-903-1.

15. Schneider, B.R. Hierarchical Capitalism in Latin America; Cambridge University Press: Cambridge, UK, 2013; ISBN 978-1-107-04163-9.

16. Cárdenas, J. Why do corporate elites form cohesive networks in some countries, and do not in others? Cross-national analysis of corporate elite networks in Latin America. Int. Sociol. 2016, 31, 341-363. [CrossRef] 
17. Mendes-Da-Silva, W. Small worlds and board interlocking in Brazil: a longitudinal study of corporate networks, 1997-2007. Braz. Rev. Finance 2011, 9, 521-548. [CrossRef]

18. Salvaj, E. Cohesión y homogeneidad. Evolución de la red de directorios de las grandes empresas en Chile, 1969-2005. In Adaptación. La Empresa Chilena Después de Friedman; Ossandón, J., Tironi, E., Eds.; Ediciones Universidad Diego Portales: Santiago de Chile, Chile, 2013; pp. 55-84.

19. Salas-Porras, A. Fuerzas centrípetas y centrífugas en la red corporativa mexicana (1981-2001). Rev. Mex. Sociol. 2006, 68, 331-375.

20. Sapinski, J.P.; Carroll, W.K. Interlocking Directorates and Corporate Networks. In Handbook of the International Political Economy of the Corporation; Nölke, A., May, C., Eds.; Edward Elgar: Cheltenham, UK, 2017.

21. Murray, J. Evidence of a transnational capitalist class-for-itself: the determinants of PAC activity among foreign firms in the Global Fortune 500, 2000-2006. Glob. Netw. 2014, 14, 230-250. [CrossRef]

22. Acemoglu, D.; Robinson, J.A. Economic Origins of Dictatorship and Democracy, Reprint ed.; Cambridge University Press: Cambridge, NY, USA, 2009; ISBN 978-0-521-67142-2.

23. DiCaprio, A. Introduction: The Role of Elites in Economic Development. In The Role of Elites in Economic Development; Amsden, A.H., DiCaprio, A., Robinson, J.A., Eds.; Oxford University Press: Oxford, UK, 2012; pp. 1-18. ISBN 978-0-19-965903-6.

24. López, M. The state of poverty: Elite perceptions of the poor in Brazil and Uruguay. Int. Sociol. 2013, 28, 351-370. [CrossRef]

25. White, H.C. Where Do Markets Come From? Am. J. Sociol. 1981, 87, 47-517. [CrossRef]

26. Wellman, B. Structural Analysis: From Method and Metaphor to Theory and Substance. In Social Structure: A Network Approach; Cambridge University Press: New York, NY, USA, 1988; pp. 19-61.

27. Schneider, B.R. Business Politics and the State in Twentieth-Century Latin America; Cambridge University Press: Cambridge, UK, 2004; ISBN 978-0-521-54500-6.

28. Moody, J.; White, D.R. Structural Cohesion and Embeddedness: A Hierarchical Concept of Social Groups. Am. Sociol. Rev. 2003, 68, 103-127. [CrossRef]

29. Organized Business, Economic Change, and Democracy in Latin America; Durand, F.; Silva, E. (Eds.) Transaction Press: New Brunswick, NJ, USA, 2000.

30. Weyland, K. “Growth with Equity" in Chile's New Democracy? Lat. Am. Res. Rev. 1997, 32, $37-67$.

31. Fairfield, T.; Garay, C. Redistribution under the Right in Latin America: Electoral Competition and Organized Actors in Policymaking. Comp. Polit. Stud. 2017, 50, 1871-1906. [CrossRef]

32. Huber, E.; Mustillo, T.; Stephens, J.D. Politics and Social Spending in Latin America. J. Polit. 2008, 70, 420-436. [CrossRef]

33. Menaldo, V. Democracy, Elite Bias, and Redistribution in Latin America. Polit. Sci. Q. 2016, 131, 541-569. [CrossRef]

34. World Bank. World Development Report 2000/2001: Attacking Poverty; Oxford University Press: New York, NY, USA, 2001.

35. Ames, B.; Brown, W.; Devarajan, S.; Izquierdo, A. Macroeconomic Policy and Poverty Reduction; International Monetary Fund: Washington, DC, USA, 2001.

36. Granovetter, M. The Impact of Social Structure on Economic Outcomes. J. Econ. Perspect. 2005, 19, 33-50. [CrossRef]

37. Krackhardt, D. The strength of strong ties: The Importance of Philos in Organizations. In Networks and Organizations: Structure, Form, and Action; Nohria, N., Eccles, R.G., Eds.; Harvard Business School Press: Boston, MA, USA, 1992; pp. 216-239.

38. Haunschild, P.R.; Beckman, C.M. When Do Interlocks Matter? Alternate Sources of Information and Interlock Influence. Adm. Sci. Q. 1998, 43, 815-844. [CrossRef]

39. Powell, W.W. Neither market nor hierarchy. Res. Organ. Behav. 1990, 12, 295-336.

40. Mizruchi, M.S. The Structure of Corporate Political Action: Interfirm Relations and their Consequences; Harvard University Press: Boston, MA, USA, 1992.

41. Heemskerk, E.M. Decline of the Corporate Community: Network Dynamics of the Dutch Business Elite; Amsterdam University Press: Amsterdam, The Netherlands, 2007.

42. Van Gunten, T.S. Cohesion, consensus, and conflict: Technocratic elites and financial crisis in Mexico and Argentina. Int. J. Comp. Sociol. 2015, 56, 366-390. [CrossRef] 
43. Gargiulo, M.; Benassi, M. Trapped in Your Own Net? Network Cohesion, Structural Holes, and the Adaptation of Social Capital. Organ. Sci. 2000, 11, 183-196. [CrossRef]

44. Burt, R.S. Brokerage and Closure: An Introduction to Social Capital; Oxford University Press: Oxford, UK, 2005; ISBN 978-0-19-924915-2.

45. Sokoloff, K.L.; Engerman, S.L. Institutions, Factor Endowments, and Paths of Development in the New World. J. Econ. Perspect. 2000, 14, 217-232. [CrossRef]

46. Lipset, S.M.; Lakin, J.M. The Democratic Century; University of Oklahoma Press: Norman, OK, USA, 2004; ISBN 978-0-8061-3618-9.

47. Boix, C. Democracy and Redistribution; Cambridge University Press: Cambridge, UK, 2003; ISBN 978-0-521-53267-9.

48. Albertus, M.; Menaldo, V. Gaming Democracy: Elite Dominance during Transition and the Prospects for Redistribution. Br. J. Polit. Sci. 2014, 44, 575-603. [CrossRef]

49. Lindert, P.H. Growing Public: Volume 1, The Story: Social Spending and Economic Growth Since the Eighteenth Century; Cambridge University Press: New York, NY, USA, 2004; ISBN 978-0-521-52916-7.

50. Moore, B. Social Origins of Dictatorship and Democracy: Lord and Peasant in the Making of the Modern World; Beacon Press: Boston, MA, USA, 1993; Volume 268.

51. Cornia, G.A. The Decline and Recent Uptick of Income Inequality in Latin America, 2002-13. In World social Science Report, 2016: Challenging Inequalities; Pathways to a Just World; UNESCO: Paris, France, 2016; pp. 201-205.

52. Hartmann, D.; Guevara, M.R.; Jara-Figueroa, C.; Aristarán, M.; Hidalgo, C.A. Linking Economic Complexity, Institutions, and Income Inequality. World Dev. 2017, 93, 75-93. [CrossRef]

53. Dion, M. Globalization, Democracy, and Mexican Welfare, 1988-2006. Comp. Polit. 2009, 42, 63-82. [CrossRef]

54. Székely, M.; Mendoza, P. Declining inequality in Latin America: structural shift or temporary phenomenon? Oxf. Dev. Stud. 2017, 45, 204-221. [CrossRef]

55. Bogliaccini, J.A.; Egan, P.J.W. Foreign direct investment and inequality in developing countries: Does sector matter? Econ. Polit. 2017, 29, 209-236. [CrossRef]

56. Cárdenas, J. Are Latin America's corporate elites transnationally interconnected? A network analysis of interlocking directorates. Glob. Netw. 2015, 15, 424-445. [CrossRef]

57. Rothstein, B. The Quality of Government: Corruption, Social Trust, and Inequality in International Perspective; University of Chicago Press: Chicago, IL, USA, 2011; ISBN 978-0-226-72957-2.

58. López-Calva, L.F.; Lustig, N.C. Explaining the Decline of Income Inequalitiy: Technological Change, Educational Upgrading and Democracy. In Declining Inequality in Latin America: A Decade of Progress; López-Calva, L.F., Lustig, N.C., Eds.; Brookings Institution Press: Harrisonburg, VI, USA, 2010; pp. 1-24. ISBN 978-0-8157-0444-7.

59. Martínez Franzoni, J.; Sánchez-Ancochea, D. The Double Challenge of Market and Social Incorporation: Progress and Bottlenecks in Latin America. Dev. Policy Rev. 2014, 32, 275-298. [CrossRef]

60. World Bank. Aspire: The Altas of Social Protection-Indicators of Resilience and Equity; World Bank: Washington, DC, USA, 2016.

61. World Bank World Bank Open Data. Available online: http://data.worldbank.org/ (accessed on 8 August 2019).

62. América Economía Ránking 100 Multilatinas 2014. Available online: http://rankings.americaeconomia.com/ multilatinas-2014/ranking/ (accessed on 1 March 2018).

63. UNCTAD UNCTADstat. Available online: http://unctadstat.unctad.org/EN/Index.html (accessed on 24 February 2018).

64. Guzmán-Concha, C. The Students' Rebellion in Chile: Occupy Protest or Classic Social Movement? Soc. Mov. Stud. 2012, 11, 408-415. [CrossRef]

65. López, M. Elite Perceptions of Inequality as a Threat to Democracy in Six Latin American Countries. In Political Inequality in the Age of Democracy: Cross-national Perspectives. London: Routledge; Dubrow, J.K., Ed.; Routledge: New York, NY, USA, 2014; pp. 95-109.

66. Ruckert, A. A Decade of Poverty Reduction Strategies in Latin America: Empowering or Disciplining the Poor? Labour Cap. Soc. Trav. Cap. Société 2009, 42, 56-81.

67. Nel, P. Redistribution with African Characteristics. Polit. South Afr. J. Polit. Stud. 2018, 45, 145-162. [CrossRef] 
68. Campello, D. The Politics of Market Discipline in Latin America: Globalization and Democracy; Cambridge University Press: New York, NY, USA, 2015; ISBN 978-1-316-23995-7.

69. Olson, M. The Logic of Collective Action; Harvard University Press: Cambridge, UK, 1965; ISBN 978-0-674-04166-0.

70. Bril-Mascarenhas, T.; Maillet, A. How to Build and Wield Business Power: The Political Economy of Pension Regulation in Chile, 1990-2018. Lat. Am. Polit. Soc. 2019, 61, 101-125. [CrossRef]

71. Useem, M. The Inner Circle; Oxford University Press: New York, NY, USA, 1984.

72. PODER La élite empresarial y la economía nacional en México: Un análisis de caso del entrecruzamiento corporativo. Available online: https://www.rindecuentas.org/reportajes/2014/11/28/la-elite-empresarialy-la-economia-nacional-en-mexico-un-analisis-de-caso-del-entrecruzamiento-corporativo/ (accessed on 17 September 2019).

73. Gasparini, L.; Lustig, A.L. The Rise and the fall of income inequality in Latin America. In The Oxford Handbook of Latin American Economics; Ocampo, J.A., Ros, J., Eds.; Oxford University Press: Oxford, UK, 2011; pp. 691-714. ISBN 978-0-19-957104-8.

74. PwC Worldwide Tax Summaries. Available online: https://www.pwc.com/gx/en/services/tax/worldwide-taxsummaries.html (accessed on 25 February 2018).

75. Castañeda, N. Business Groups, Tax Efficiency, and Regressivity in Colombia. In Rethinking Taxation in Latin America; Atria, J., Groll, C., Valdés, M.F., Eds.; Palgrave Macmillan: Cham, Switzerland, 2018; pp. 187-211. ISBN 978-3-319-60118-2.

(C) 2019 by the author. Licensee MDPI, Basel, Switzerland. This article is an open access article distributed under the terms and conditions of the Creative Commons Attribution (CC BY) license (http://creativecommons.org/licenses/by/4.0/). 